WHOSE SMART CITY?: A FRAMEWORK AND DISCUSSION GUIDE FOR PLANNING OPEN AND INCLUSIVE URBAN DIGITAL EXPERIMENTS

\author{
Steven Coutts \\ BA (Hons), University of Winnipeg, 2016
}

\begin{abstract}
A Major Research Project
presented to Ryerson University
\end{abstract}

in partial fulfillment of the

requirements for the degree of

Master of Planning

in the Program of

Urban Development

Toronto, Ontario, Canada, 2018

(C) Steven Coutts, 2018 


\section{Author's Declaration for Electronic Submission of MRP}

I hereby declare that I am the sole author of this MRP. This is a true copy of the MRP including any required final revisions.

I authorize Ryerson University to lend this MRP to other institutions or individuals for the purpose of scholarly research.

I further authorize Ryerson University to reproduce this MRP by photocopying or by other means, in total or in part, at the request of other institutions for the purpose of scholarly research.

I understand that my MRP may be made electronically available to the public. 


\title{
WHOSE SMART CITY?: A FRAMEWORK AND DISCUSSION GUIDE FOR PLANNING OPEN AND INCLUSIVE URBAN DIGITAL EXPERIMENTS
}

\author{
(C) Steven Coutts, 2018 \\ Master of Planning \\ in \\ Urban Development \\ Ryerson University
}

\begin{abstract}
'Smart cities' represent the integration of 'big data' collected via networked cameras, sensors, and meters into the urban fabric with the overarching goal of making infrastructure more efficient and improving citizens' lives. While data has been used to support planning efforts for decades, this new paradigm of 'urban informatics' means that planning will increasingly be driven by data. However, the planning profession is still grappling with how existing practices might need to adapt to tackle the challenges of planning in the smart city. Accordingly, there is a gap in terms of educational resources on smart cities aimed at planning professionals. Through an action research approach involving a review of recent academic and popular literature on smart cities, this project synthesizes a set of 'best practices' and proposes a discussion guide for planning professionals to learn about the implications for their practice in a world where big data shapes our cities.
\end{abstract}

Keywords: smart cities, urban informatics, planning ethics, Big Data, citizen participation 


\section{Acknowledgements}

First of all, I would like to express my sincerest thanks to my supervisor, Dr. Pamela Robinson, for the incredible support she has given me throughout the process of writing this MRP. From the first inklings of a research idea, through many (many) iterations, to the final project, Pamela has inspired and challenged my thinking, always with humour and patience. There is no doubt that this research project exists in large part due to her confidence in me and generosity in sharing her ideas.

I wish to express my thanks to Professor Nina-Marie Lister for acting as my second reader. Additionally, I would like to thank Bianca Wylie for her insightful feedback on the discussion guide portion of this MRP.

Finally, I want to thank my colleagues and friends in the Master of Planning program especially Amanda Mackaay and Olivia Magalhaes - for the support they have shown me. The past (almost) two years spent working side-by-side with some of the most amazing, bright individuals has been daily confirmation that uprooting myself from the Prairies was the right choice and that I cannot imagine having completed my graduate education anywhere else. 


\section{Table of Contents}

Author's Declaration for Electronic Submission of MRP ......................................................................................

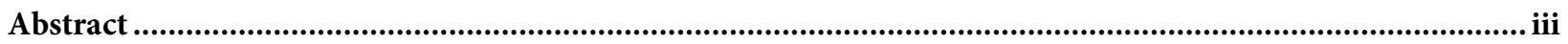

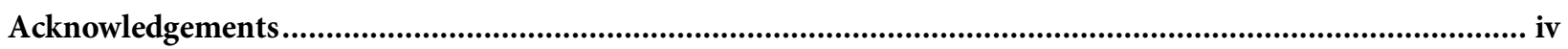

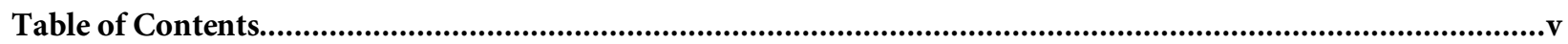

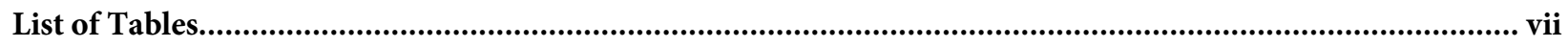

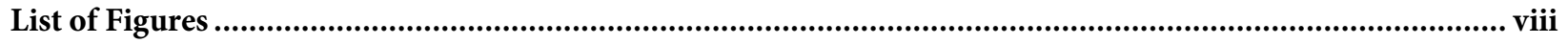

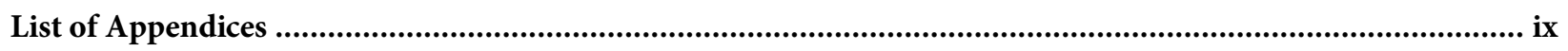

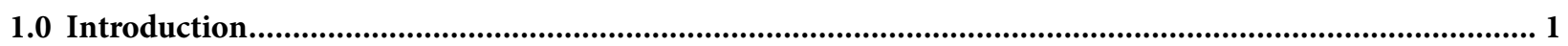

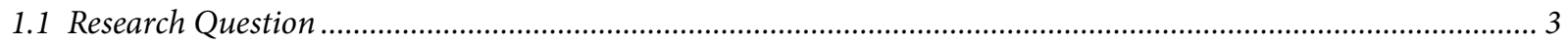

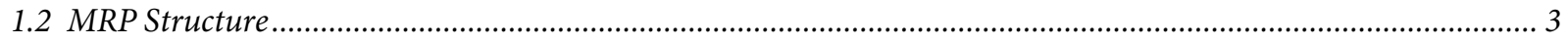

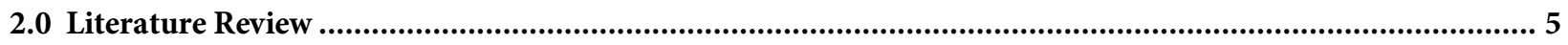

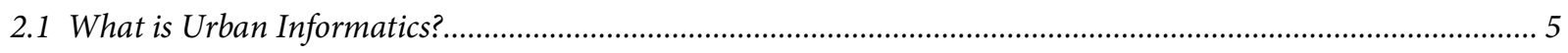

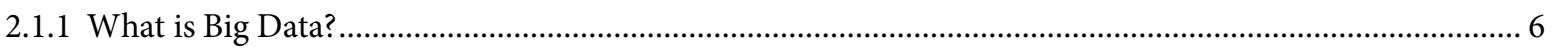

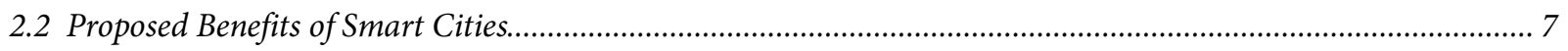

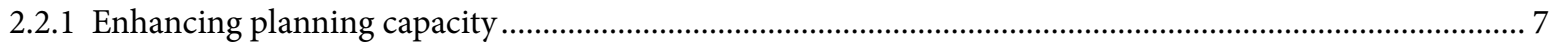

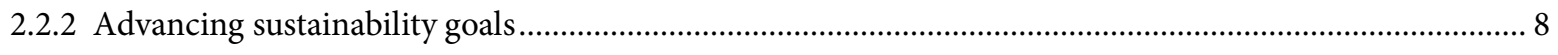

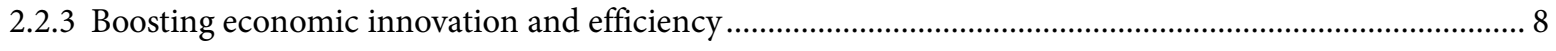

2.2.4 New avenues for civic engagement ................................................................................................. 9

2.3 Concerns and issues about smart cities from a planning perspective.............................................................. 10

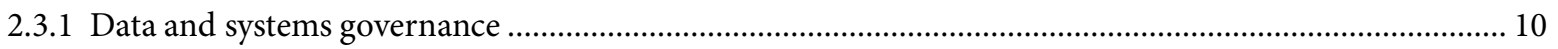


2.3.2 Ethics, privacy and security concerns

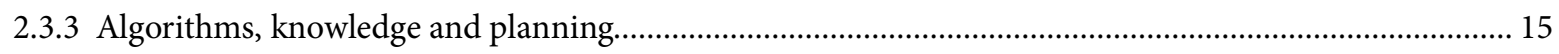

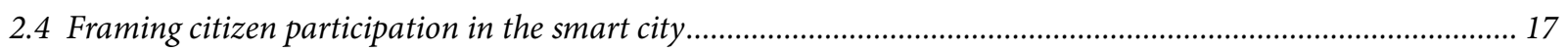

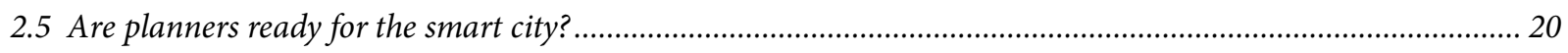

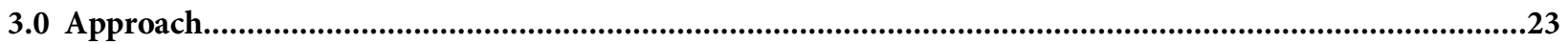

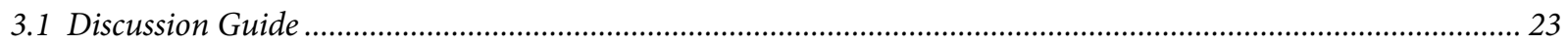

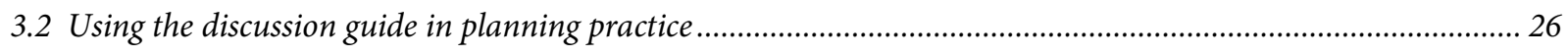

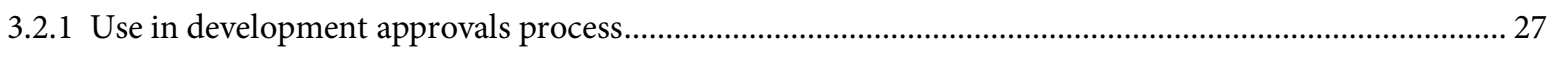

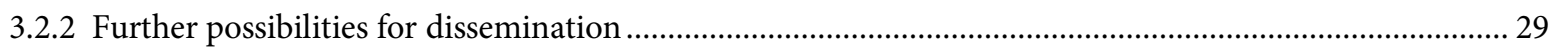

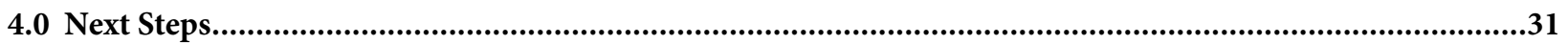

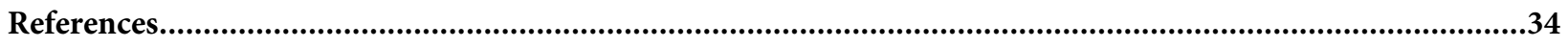

Appendix A: Smart City Technologies and their Applications to City Systems ..............................................A

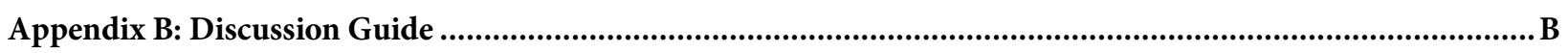




\section{List of Tables}

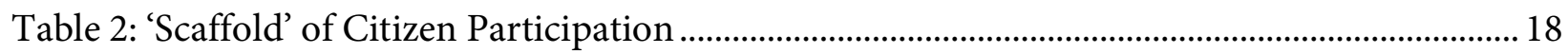

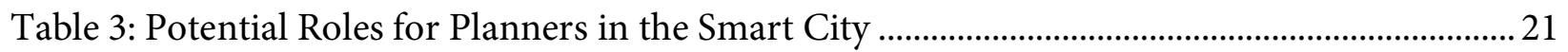

Table A-1: Smart City Technologies and their Applications to City Systems................................. A1 


\section{List of Figures}

Figure 1: City of Toronto Official Plan and Zoning By-law Amendment Process Flowchart........ 29 


\section{List of Appendices}

Appendix A: Smart City Technologies and their Applications to City Systems

Appendix B: Discussion Guide...... 


\subsection{Introduction}

'Smart cities' have increasingly emerged in planning discourse as a shorthand for the integration of 'big data' (i.e., fine-grained, real-time, exhaustive data) collected via the 'Internet of Things' (e.g., networked cameras, sensors, meters, GPS, etc.) into the urban fabric with the overarching goal of making infrastructure more efficient and improving urban dwellers' lives. While data has been used to support planning efforts for decades, this new paradigm of 'urban informatics' means that planning will increasingly be driven by data. And although big data has already begun to make its mark on Canadian cities, two initiatives on the horizon promise to boost its profile further: The Smart Cities Challenge and the Sidewalk Toronto project.

The Smart Cities Challenge is a $\$ 300$ million competition launched by the Canadian federal government in fall of 2017 in which they pledged to "work in collaboration with cities and communities that are ready to innovate and take risks - providing financial and in-kind support for their smart cities transformation." While few details have been revealed thus far, the competition will consist of three rounds, with prizes for each of three rounds including one large prize of $\$ 50$-million, two prizes of $\$ 10$-million for mid-sized communities, one prize of $\$ 5$ million for a small community, and one prize of \$5-million available for an Indigenous community.

Sidewalk Toronto is a new partnership between Sidewalk Labs and Waterfront Toronto to develop a Master Innovation and Development Plan for the 4.9 hectare 'Quayside' site adjacent to the Port Lands. In March 2017, Waterfront Toronto - a trilevel government agency which oversees development along Toronto's waterfront - issued a request-for-proposals seeking an "innovation and funding partner" for this venture. The winning bid was submitted by 
Sidewalk Labs - a subsidiary of Alphabet (formerly Google) (Bloomberg News, 2017) which committed \$50 million in initial investment towards pilot sustainability projects (Lorinc, 2017) and a year-long public engagement plan consisting of public roundtable meetings, pop-up stations, a citizen reference panel, design jams, and more (Sidewalk Toronto, 2018). It is important to note that, at this point, no land has changed owners (Wylie, 2018); Sidewalk Toronto won the right to develop a plan for the Quayside site but Waterfront Toronto has the right to terminate the agreement at any point if the project does not meet their specifications.

If Sidewalk Toronto's plan gets the green light, Toronto - or a small piece of it at least - is set to become an urban living lab for emerging technologies (Cardullo \& Kitchin, 2017b). But while this project is highly visible, smart city technology and urban informatics are already here in the form of many smaller, less visible interventions in our daily lives involving increased automation and embedding of sensors, algorithms, and artificial intelligence into the urban landscape. These technologies have the potential to realize improvements to the way our cities operatre, but they also bring with them a myriad of concerns with which the planning profession has not yet fully come to terms.

These projects raise the question: Where do people fit into this new paradigm? Will citizen participation take a passive form, for example, through apps such as SeeClickFix that allow a person to alert the appropriate municipal department about services and infrastructure in need of attention (e.g., street lights, garbage pickup, graffiti). Or will it consist of substantive engagement via platforms which encourage not only citizen participation but co-creation of solutions, opening up and transforming decision-making processes across municipal governance and city planning (Cardullo \& Kitchin, 2017a)? 
Moreover, as advocates for the public interest, how can planners assess the degree to which broader smart city policies reflect potential impacts on citizens (Wiig, 2016)? Is there a role for planners to help ensure smart technology does not become an end in itself but rather a tool for building more open and inclusive civic realm? On this score, I will provide some preliminary guidance through this major research project.

\subsection{Research Question}

This major research project has been guided by this central question:

- How can planning professionals - public, private, or third sector - strive to ensure that openness and inclusivity are embedded in smart city projects, such that all urban citizens, especially those belonging to marginalized communities, are able to engage in a meaningful way?

\subsection{MRP Structure}

Accordingly, I will begin by introducing a working definition of the smart city - specifically the combination of 'big data' and the 'Internet of Things'. Next, several proposed benefits of smart city will be outlined, including overall implications for planning as well as three broad areas: 1) improved economic efficiency and competitiveness; 2) advancement of sustainability goals, and;

3) enhanced civic engagement. Next, three areas of concern regarding smart cities will be explored: 1) data and systems governance; 2) ethics, privacy and security, and; 3 ) the nature of data and knowledge in the smart city. The following sections will explore the various ways in which citizen participation and the role of the planning profession have been framed in smart city discourse, and the gap between this framing and the reality of current planning practice. This project is a preliminary attempt to address that gap, mobilizing academic knowledge in the form 
of an educational guide aimed at planners. It is hoped that this resource will equip planning professionals working across all sectors with the basic knowledge needed to understand big data and smart city technology and the issues and concerns relevant to planning practice. Finally, this paper will close with potential future directions for this timely domain of planning research and practice. 


\subsection{Literature Review}

Smart city research has been a burgeoning field in the last decade and, as such, any attempt to exhaustively summarize it would be futile. This literature review will give a brief overview of certain key technological concepts which are useful to grasp before proceeding to a discussion of proposed benefits of smart cities and their associated technology. Following that, I will turn to three key areas of concern that have been identified in the literature as posing particular challenges for planners. A recurrent theme in the literature revolves around the role of citizen participation in the smart city, therefore I will discuss some models for conceptualizing how people might fit into this new paradigm of urban informatics. Lastly, the planning profession, although it is concerned with the public interest, is currently ill-equipped to navigate what it might mean to practice planning in the smart city. Introducing the issues synthesized from the corpus of smart city research in this way will set the stage for my proposed intervention - the development of a discussion guide for planners - as well as how the planning profession should move forward on smart cities.

\subsection{What is Urban Informatics?}

Urban informatics (Sadoway \& Shekhar, 2014; Schweitzer \& Afzalan, 2017), as mentioned in the introduction, is a term used throughout this paper to refer to 'big data', collected via sensors, cameras, meters and other components of the 'Internet of Things' (IoT) and its use in constructing connected systems and interfaces that together allow for a synoptic, real-time view of urban conditions, including the built environment and citizens. 


\subsubsection{What is Big Data?}

Compared with traditional data (e.g., censuses, surveys, administrative records) which represents a selective snapshot in time and is necessarily limited in scope, big data is - as the name suggests - comprised of vast quantities of data points. This can allow for a fine-grained, real-time understanding of a system, provided the appropriate degree of infrastructure and organizational coordination is in place (Kitchin, 2014a).

But how is 'big data' measured and collected? The so-called 'Internet of Things' - which includes digital cameras, sensors, transponders, meters, actuators, GPS, and other pieces of technology all connected via the Internet - measures and tracks current conditions on the ground, uploading data to cloud servers continually. Apart from this dedicated data collection infrastructure, smartphone apps, sharing economy platforms (e.g., Uber, Yelp, etc.) and (eventually) automated vehicles generate a range of location, movement and activity data (Kitchin, 2014b; Kitchin, Lauriault, \& Wilson, 2017).

The power of big data is unleashed through algorithms (Kitchin, 2016a). All software is made up of algorithms - sets of defined steps structured to process instructions/data to produce an output (e.g., a recipe is an algorithm most of us are familiar with). Algorithms are involved in many everyday practices and tasks, like searching, secure encrypted exchange, recommendation, pattern recognition, data compression, auto-correction, routing, predicting, profiling, simulation and optimization. As artificial intelligence and machine learning become more common, algorithms will be able to continually tweak and optimize themselves without any human intervention (Kitchin, 2016b). As we will see, this new computing paradigm has expansive implications for cities. 


\subsection{Proposed Benefits of Smart Cities}

In essence, smart city proponents assert that by combining data analysis with urban governance and planning, cities can realize a host of benefits (Appendix A) including: 1) enhancing their overall ability to plan, model, and coordinate complex systems; 2) advancing sustainability through energy efficiency, reduced congestion, and improved public transit; 3) encouraging economic innovation, competitiveness, and efficiency, and;4) becoming more accessible to their citizens with expanded opportunities for citizen participation and engagement (Robert G. Hollands, 2008; Kitchin, 2014b; A. Luque-Ayala \& Marvin, 2015).

\subsubsection{Enhancing planning capacity}

How does big data and smart technology change how we plan our cities? Planning has always been informed by data - whether in the form of statistics, scientific data, derived data, or data from consultation activities. The difference is a matter of scale, with smart city technology complementing these traditional data sources with large amounts of real-time, crowdsourced, and location-based data. As mentioned above, in an optimal setting where there is a high enough degree of infrastructure and coordination between municipal departments, data can be continually sent to city operating systems, intelligent transport systems, logistics management systems, smart energy grids, and building management systems that can process and respond in real-time to the data flow. 'Urban dashboards' enable city planners and citizens to visualize and interact with a range of data, such as key performance indicators and real-time as opposed to reported values (Kitchin, Lauriault, \& McArdle, 2015a).

The ability to model, simulate, and visualize an array of urban conditions and systems is a transformative impact of urban informatics. For example, instead of a one-time traffic count, one could visualize patterns of travel or pollution across times of the day, days of the week, and 
seasons, and for all points on a network (for example, intersections, bus stops, sensor locations), allowing for more targeted, efficient interventions. Further specific examples of big data and associated smart city applications are described in Table A-1.

\subsubsection{Advancing sustainability goals}

In a broad sense, urban informatics may finally help solve the issue of externalities as they relate to environmentally destructive behaviour. Current (as well as future) generations face pressing environmental challenges on an unprecedented scale such as anthropogenic climate change, pollution, habitat degradation, energy scarcity and natural resource depletion (Halpern \& Günel, 2017). The capacity for continuous data collection and analysis may allow for sophisticated policy responses whereby behaviours contributing to, for instance, greenhouse gas emissions, can be assigned a cost and curtailed accordingly. Embedded sensors which regulate and allow for smart pricing of energy and optimizing the performance and efficiency of our built environment show similar promise (Cosgrave, Arbuthnot, \& Tryfonas, 2013). By accurately monitoring and making available better information about who is polluting and how much, our governments should be able to design more effective, evidence-based policy responses with the ability to make adjustments until the desired outcome is achieved. One of the stated goals of smart city initiatives such as the Sidewalk Toronto development (Sidewalk Labs, 2017) is to create a testbed (Caprotti \& Cowley, 2016) for novel technologies and enable upscaling of successful ones in order to mount a serious challenge to the aforementioned problems.

\subsubsection{Boosting economic innovation and efficiency}

Financing essential infrastructure has long been a challenge in Canadian cities, as they fall squarely under the purview of the provincial government as 'creatures of the province'. Apart from transfer payments from senior levels of government, cities have a limited menu of options - 
predominantly property taxes and user charges - at their disposal when it comes to raising revenues to support their infrastructure (McAllister, 2004). This, combined with generally cautious political attitudes towards governmental expenditures means that any solution which allows municipalities to "do more with less" tends to be embraced. Smart city solutions promise to allow for more efficient and cost-effective deployment of civic resources through the generation and analysis of complex data sets which can be used to continually optimize the performance of municipal systems (Table 1). On the private sector side, urban informatics could support new types of employment, accelerate productivity and give urban economies as a whole a competitive advantage over other jurisdictions.

\subsubsection{New avenues for civic engagement}

Finally, urban informatics promises to usher in a new era of civic participation and accountable governance. New data streams will feed into robust evidence-based decision-making processes and enable better service delivery. E-government platforms will provide an interface through which citizens can more easily participate in democratic processes. 'Open by default' civic data would be available to developers and citizens alike, building off of the 'hackathon' movement where members of the civic technology community gather to apply open data set to practical collective issues (Robinson \& Johnson, 2016). Overall, it is envisioned that smart cities will create 'smart citizens' who are more informed, creative, and empowered than would have previously been possible (Schuler, 2016), an idea that will be explored and challenged in greater detail in later sections.

It is important to note, however, that these are normative predictions of how smart city technology might be used to the greatest societal benefit. As we shall see in the following section, there is no guarantee that simply having the means by which to measure, analyze, and optimize 
our urban environments via sensors, algorithms, and AI will, on its own, produce transparent, equitable or just outcomes.

\subsection{Concerns and issues about smart cities from a planning perspective}

Urban informatics, while less visible than the built environment, will profoundly change the way citizens experience urban space. As outlined in the previous section, this has the potential for the realization of real benefits (Cities for People, 2018). These include understanding existing usage of capacity, helping to effectively plan for services, gathering more information on existing infrastructure conditions, and developing actions in order to influence citizens' behaviours towards more sustainable and cost-effective ones (Cruz \& Sarmento, 2017).

But do the potential benefits outweigh the drawbacks? Many critics (Kitchin 2014; Schweitzer \& Afzalan, 2017) have noted serious concerns with regards to urban informatics. While this section does not attempt to produce an exhaustive list, it outlines three key areas of concern that impact the planning profession: 1) Data and systems governance; 2) Ethics, privacy and security concerns, and; 3) The nature of data and knowledge generated in the smart city.

\subsubsection{Data and systems governance}

How is urban informatics and its associated infrastructure actually implemented? The prevailing climate of fiscal restraint (if not austerity) in which many North American governments find themselves often translates into reluctance to commit to major infrastructure investments. The request-for-proposals (RFP) issued for the Quayside site by Waterfront Toronto - the agency responsible for directing development on the city's waterfront - summed up this state of affairs as follows:

Government funding is constrained and there exists a large list of competing infrastructure projects. In collaboration with the private, public and not-for-profit sectors, Waterfront Toronto must seek out new and innovative partnerships, funding and 
investment models that enable our projects, address our goals and recognize and mitigate diminishing government funds. (Waterfront Toronto, 2017)

Public-private partnerships have been seen as an attractive solution, from the perspectives of both the government and the private sector. Governments can leverage private equity can finance public infrastructure, with the risks of financing, building and maintaining the infrastructure built into the cost (to taxpayers) and amortized over a period of time (Yuan \& Zhang, 2016). In turn, urban informatics sector partners benefit from the stability of having a government as a customer, as well as predictable returns on investment and entry into a lucrative market with a more-or-less replicable model.

The privatization and competitive management of public infrastructure is not a new phenomenon (Grossi \& Pianezzi, 2017; Harvey, 1989). However, smart cities provide a new context, a new stage on which this process can be enacted (de Cordova, 2018). One major concern is how the actual contracting for smart cities data and infrastructure within a P3 context ${ }^{1}$ affects transparency. For example, who actually owns the data generated, and what are the terms and conditions under which they can distribute it to a wider audience? This can have important implications for those seeking access to information used in planning decisions or seeking open data for a broad range of purposes. Kitchin et al. (2017) have noted cases in which private firms offer consultancy services or funding for smart city initiatives on the condition that the city adopt

\footnotetext{
${ }^{1}$ Cruz and Sarmento (2017, p. 4) identify three main categories of smart city P3s: 1) "Business as usual" P3s, which are typical build-operate-transfer (or build-own-operate-transfer) projects or agreements for the operation of systems generally involving long term contracts, ( 20 years or more), and involve significant private sector financing; 2) "Incremental innovation" P3s are developed for partial subsystems, for example ticketing systems, fleet management. These technological upgrades to existing systems do not represent a wholesale restructuring of the main system, but rather. upgrade the service, maintain existing business models and structures, and; 3) "Groundbreaking innovation" P3s - disruptive improvements, whereby new business and service models are built and implemented.
} 
new performance management practices or give access to otherwise restricted data. This allows these firms to gain a perpetual competitive advantage by integrating their products into urban systems such that they become indispensable, creating "technological lock-in" (Kitchin, 2014b). Municipalities purchasing technology from vendors run the risk of investing significant sums of public funds into a proprietary solution, essentially locking them in to particular platforms and vendors for long periods of time. Especially in the case of new, rapidly changing (and potentially untested) technologies, municipalities often do not possess the expertise to fully understand - and hence be able to properly evaluate - these products before procuring them. As Kitchin et. al (2017, p. 15) note, "cities have a long history of purchasing technologies that are costly and do not always deliver on their promises."

The profit imperative entailed by private sector collaboration may mean the prioritization of smart city initiatives which are likely to generate the most economic return-on-investment as opposed to those producing less tangible, but nonetheless real social benefits. To date, much of the current driving force behind adoption of urban informatics and systems has originated from “vendor push [as opposed to] city government push" (Bélissent, 2010, p. 20).

Developing, implementing, and managing urban informatics through the use of P3s differs from their use with more traditional 'hard' infrastructure (e.g., bridges, highways, hospitals, etc.) in several key ways. Traditional P3s usually entail that, after a certain period of time, the asset/infrastructure designed and built (and/or operated, managed, etc.) through the P3 reverts back to public ownership (Canadian Council for Public-Private Partnerships, 2011). This does not usually present a problem, since the expertise required to operate and maintain the infrastructure usually already exists in the public sector. But how can this model be applied to urban informatics? If the time comes to take back ownership of the infrastructure, will the 
municipality have the financial capacity or institutional expertise to continue to operate and maintain this smart infrastructure?

In the competition among cities to implement smart technologies first, vendors have a vested interest in mass-producing and marketing their products to as many customers as possible (Kitchin, 2014b). For example, IBM sells its 'IBM Intelligent Operations Center' - first developed for Rio de Janeiro as a way of simultaneously monitoring and coordinating responses to a multitude of urban infrastructural systems (Andrés Luque-Ayala \& Marvin, 2016) - as an 'outof-the-box' product for use in cities around the globe. The resulting overreliance on the expertise of vendors, consultants and the broader community of "urban technocrats" can lead to the procurement of technologies or systems that are ill-adapted to local conditions (Kitchin, Coletta, et al., 2017). Municipalities must exercise caution in adopting smart city solutions to ensure not only that procurement processes are based on sound decision-making, but also that the public interest is not put at risk.

\subsubsection{Ethics, privacy and security concerns}

Smart city technologies (including machine learning, urban informatics, and data science) are rooted in a positivist, scientific tradition. The systematic data collection, cataloguing, and analysis enabled under the Big Data paradigm allows for the reconfiguration and creation of new data assemblages and relationships, informing and optimizing all spheres of human activity. This high-powered "seeing like a state" (Scott, 1998, p. 5) can make previously invisible phenomena legible (e.g., through censuses, inventories, classification schemes, etc.). However, monitoring individuals' behaviour in public spaces and collecting and storing their data raises serious ethical questions around privacy and consent, especially if that consent is coerced or uninformed. This has ramifications for individual privacy, since the omnipresence of sensors collecting inputs 
would intrude significantly on an even greater proportion of our activities. While one proposed positive use of smart city technology is that it would allow us to 'nudge' individuals into making behavioural changes that benefit society (e.g., incentivizing transit over automobile use), even this has potentially negative applications. For example, marginalized groups (e.g., Black, Indigenous, persons of colour, individuals experiencing homelessness, mental health, or addiction issues) who already receive disproportionate attention from law enforcement might become subject to even greater levels of surveillance. As Virginia Eubanks (2017, p. 7) notes in Automating Inequality, this increased data collection "acts to reinforce their marginality when it is used to target them for suspicion and extra scrutiny". The use of data for 'spatial sorting' to exclude persons from places or services (Murakami Wood, 2017), the (in)ability to opt in/out of smart city zones, as well as control and disposal of personal data collected all present serious dilemmas that will need to be addressed in the 'panoptic city' (Kitchin, 2014b).

Additionally, given that the smart city relies on vast amounts of computer processing power, it is perhaps not surprising that experts have pointed out how vulnerable such a network might be to technical bugs and glitches as well as hacking or cyber attacks (Kitchin, 2014b). The proliferation of "code/spaces" (Dodge \& Kitchin, 2005) - in which physical space and software are mutually constitutive - means that, in the event of a systems failure, the space can no longer function as designed, nor is there a 'manual override' to return it to its pre-smart state. For example, a power outage at a grocery store means that no items can be scanned at the checkout nor any payments processed, and a failure of the automatic signalling technology in subway system means the trains will simply not run. As well, the more interdependencies existing within the smart city, the greater the disruption the failure of any one system will cause. 
These networked interdependencies are also why intentional hacking of the same systems has been highlighted as an area for concern. Substandard security and encryption measures, insecure legacy systems (holdovers from the pre-smart city era), multitude of access points, and ability to cause a cascade effect of damage with relatively little effort are several reasons why urban informatics systems might make attractive targets for hacking and cyber attacks. Suggested responses to these issues include technological measures such as stronger encryption, controls on access, redundancy, and ensuring up-to-date patching as well as policy-based measures such as Privacy by design (Kitchin, 2014b). However, these vulnerabilities point to a larger issue: how can we trust our city's functions to systems when few of us know how they work?

\subsubsection{Algorithms, knowledge and planning}

In essence, smart city technology is premised on the notion that the city can be reduced to a set of knowable, legible, and manageable systems acting in a deterministic fashion which can be controlled and optimized through technological interventions (Kitchin, Lauriault, \& McArdle, 2015b). It is claimed that smart city initiatives, through their ability to collect, analyze and disseminate vast amounts of data, hold extraordinary promise in terms of helping average citizens achieve a greater degree of participation in municipal processes (Cardullo \& Kitchin, 2017a). Many municipalities have taken steps in this direction, by introducing open data portals or civic dashboards - a 'one-stop-shop' with visualizations of services, socioeconomic snapshots, key performance indicators, and assorted data points from various municipal departments and agencies (Kitchin et al., 2015a). Municipal decision-making and service delivery will increasingly be driven by big data and algorithms, but how do people fit into these processes? How can they contribute to the building of the smart city if because of its 'black box'-like nature (Pasquale, 
2015) - they cannot easily 'look inside' and question how they work and challenge the assumptions they are making or the outcomes they produce?

While smart cities run on vast amounts of data, in its raw, unfiltered state, these data are useless to most people unless they have specific training in data management and analysis. Without critical data skills, it is difficult to tell the difference between high and low-quality data. Even though there are limitations to data and algorithmic transparency (B. Wylie, personal communication, April 3, 2018), this has profound implications for grassroots efforts to actually make use of data to understand problems or create solutions at the local level. Disparities in data literacy could therefore lead to a new 'digital divide', advantaging those in control of data (e.g., large companies) and excluding others (small businesses, marginalized individuals).

Increased computing power has, consistent with Moore's law, expanded the capacity for data collection by many orders of magnitude. But the collection of any data - even 'big data' necessarily entails a reductionist approach, quantifying individual data points and positing deterministic (perhaps probabilistic as artificial intelligence develops) relationships between them (Halpern, Lecavalier, Calvillo, \& Pietsch, 2012). Adapting insights from Scott (1998, p. 87) on "seeing like a state", there is a danger with regards to smart city interventions involving "big data', algorithms, sensors, and AI that they are "designed to summarize precisely those aspects of a complex world that are of immediate interest to the mapmaker and to ignore the rest." A common theme within much of the critical literature is the importance of integrating situated, lived knowledge and experience with the emergent smart city paradigm. Kitchin, Lauriault and McArdle (2015a, pp. 24-25), for example, advocate for "initiatives that do not make grand claims as to their veracity or validity, or assert their instrumental rationality and in so doing actively 
work to close off other ways of knowing [...]”. In the next section, I will discuss how local knowledge and lived experience might be (re)positioned in the context of the smart city.

\subsection{Framing citizen participation in the smart city}

As detailed in the previous section, place-based knowledge, lived experience, and alternative ways of knowing may struggle to find a home in this new world of data. However, this is at odds with many planners' view of cities, which is that they are complex, always-changing places filled with a multitude of publics, actors, relationships, competing interests, divergent histories and politics. These conditions, as planners understand them, necessitate a more nuanced, people-centred approach toward planning.

There are numerous ways of assessing public participation processes, including IAP2's Spectrum of Public Participation (2014) and Zuckerman's (2013) 2-D matrix of citizen engagement exercises, ranging from "thin" to "thick" on the y-axis, "symbolic" to "impactful" on the x-axis. Cardullo and Kitchin (2017a, p. 18) provide a potentially useful starting point with their 'scaffold of smart citizen participation'- adapting Arnstein's 'ladder of citizen participation'. This heuristic evaluates how citizens' roles are framed in the context of smart city initiatives (ranging from non-participation, consumerism, tokenism, and citizen power). 
Table 2: Scaffold of Citizen Participation (adapted from Cardullo \& Kitchin, 2017a)

\begin{tabular}{|c|c|c|c|c|c|}
\hline \multicolumn{2}{|c|}{$\begin{array}{c}\text { Form and Level of } \\
\text { Participation }\end{array}$} & Role & $\begin{array}{c}\text { Citizen } \\
\text { Involvement }\end{array}$ & $\begin{array}{c}\text { Political } \\
\text { discourse/framing }\end{array}$ & Modality \\
\hline \multirow[t]{6}{*}{ Citizen Power } & Citizen & Leader, & Ideas, & Rights, & \multirow{6}{*}{$\begin{array}{l}\text { Inclusive, } \\
\text { Bottom-up, } \\
\text { Collective, } \\
\text { Autonomy, } \\
\text { Experimental }\end{array}$} \\
\hline & Control & Member & \multirow{4}{*}{$\begin{array}{l}\text { Vision, } \\
\text { Leadership, } \\
\text { Ownership, } \\
\text { Create }\end{array}$} & \multirow{4}{*}{$\begin{array}{l}\text { Social/Political } \\
\text { Citizenship, } \\
\text { Commons }\end{array}$} & \\
\hline & Delegated & Decision- & & & \\
\hline & Power & maker, & & & \\
\hline & & Maker & & & \\
\hline & Partnership & Co-creator & $\begin{array}{l}\text { Negotiate, } \\
\text { Produce }\end{array}$ & \multirow[t]{2}{*}{$\begin{array}{l}\text { Participation, Co- } \\
\text { creation }\end{array}$} & \\
\hline \multirow[t]{5}{*}{ Tokenism } & Placation & Proposer & Suggest & & \multirow{9}{*}{$\begin{array}{l}\text { Top-down, } \\
\text { Civic } \\
\text { Paternalism, } \\
\text { Stewardship, } \\
\text { Bound-to- } \\
\text { succeed }\end{array}$} \\
\hline & Consultation & Participant, & Feedback & Civic Engagement & \\
\hline & & Tester, & & & \\
\hline & & Player & & & \\
\hline & Information & Recipient & \multirow{2}{*}{$\begin{array}{l}\text { Browse, } \\
\text { Consume, } \\
\text { Act }\end{array}$} & & \\
\hline Consumerism & Choice & $\begin{array}{l}\text { Resident, } \\
\text { Consumer }\end{array}$ & & $\begin{array}{l}\text { Capitalism, } \\
\text { Market }\end{array}$ & \\
\hline \multirow{3}{*}{$\begin{array}{l}\text { Non- } \\
\text { participation }\end{array}$} & Therapy & \multirow{3}{*}{$\begin{array}{l}\text { Patient, } \\
\text { Learner, } \\
\text { User, } \\
\text { Product, } \\
\text { Data-point }\end{array}$} & \multirow{3}{*}{$\begin{array}{l}\text { Steered, } \\
\text { Nudged, } \\
\text { Controlled }\end{array}$} & \multirow{3}{*}{$\begin{array}{l}\text { Stewardship, } \\
\text { Technocracy, } \\
\text { Paternalism }\end{array}$} & \\
\hline & Manipulation & & & & \\
\hline & & & & & \\
\hline
\end{tabular}

To put these in concrete terms, at the more passive level of participation, for example, adoption of third-party apps such as SeeClickFix provide a means for anyone to alert the appropriate municipal department about services and infrastructure in need of attention (e.g., street lights, garbage pickup, graffiti). In one sense, this can be seen as a partial outsourcing of monitoring infrastructure state-of-good-repair to citizens, which can allow for more strategic deployment of maintenance staff and resources (Walravens \& Ballon, 2013). At the other end of the spectrum are platforms which could enable not only citizen participation but also co-creation of data sets and solutions which can inform decision-making in areas such as governance and budgeting (Cardullo \& Kitchin, 2017a). The Quayside vision (Sidewalk Labs, 2017), for example, proposes the piloting of an application called Neighbourhood Assistant which will facilitate social 
coordination and public feedback, enable residents to form new neighbourhood groups, crowdsource community needs, and access a peer-to-peer marketplace.

Smart cities have, over time, become subject to differing discursive framings. Kummitha and Crutzen (2017, p. 50)- in their meta-analysis of smart city research - have identified four 'schools' of smart city thought: the (1) 'restrictive' and (2) 'reflective' schools focus mainly on the positive gains associated with urban informatics; the (3) 'rationalistic' school emphasizes that technology adoption needs to be coupled with human agency; (4) the 'critical' school challenges the inclusive claims of the other schools and argues that any benefits realized through urban informatics will mainly accrue to elites.

In recent years, the fourth school of thought - a critical discourse - has emerged among academics concerned with the smart city, which attempts to formulate what an alternative smart urbanism might look like. However, no well-formed consensus has emerged on what that might be. McFarlane and Söderström, for example (2017, p. 5), caution against the adoption of overly prescriptive criteria and urge academics

to go beyond the list-like frameworks for alternative [Smart Urbanism]. A checklist is precisely the sort of argument that corporations have the capacity to digest. It is a form of critique that they can easily absorb, because the corporate discourse on [Smart Urbanism] is designed to be expansive.

It is within this critical discourse that the following section envisions the planning profession occupying. Exploring how the needs of "multiple publics" (Sandercock, 2003, p. 34) are accounted for is an especially germane endeavour to the urban planning profession in Toronto one of the world's most culturally diverse cities. Against the backdrop of entrenched spatial patterns of socioeconomic disparity in the City of Toronto, many citizens, especially those belonging to marginalized groups are increasingly pushed farther away from essential services 
and opportunities (Hulchanski, 2010) and are therefore unable to truly exercise their 'right to the city'.

However, the 'right to the city' goes deeper than just being able to meet one's basic survival needs; it implies agency and the power of individuals to actively shape their environment. And while savvier vendors of urban informatics claim to have absorbed this message (McFarlane \& Söderström, 2017), “citizen engagement [is] not always incorporated by the governments that purchase the advice and technological development from the smart city vendors" (Schuler, 2016). The next section will offer insights on how the planning profession might foster an open and inclusive smart city environment.

\subsection{Are planners ready for the smart city?}

The smart city will be a paradigm shift in many ways. But what does it mean for planners? It almost certainly does not mean planners must go back to the drawing board completely. Instead, planners must refocus on the mission of their profession - serving the public interest. This means, among other things, creating smart citizens who are not simply "tenders of the smart city apparatus" (Schuler, 2016). On this score, Concilio (2016, pp. 33-35) envisions a variety of differentiated roles for planners (Table 3). 
Table 3: Potential Roles for Planners in the Smart City

\begin{tabular}{ll}
\hline Role for Planner & Description \\
\hline $\begin{array}{l}\text { Enabler of } \\
\text { practices }\end{array}$ & $\begin{array}{l}\text { Nurture creative and novel practices while creating space for mutual learning and new } \\
\text { forms of citizenship }\end{array}$ \\
\hline Laboratory manager & Discover new modes of city-making for and with citizens \\
\hline Boundary spanner & $\begin{array}{l}\text { Facilitate cross-boundary work by acting as brokers (e.g., between multiple actors and } \\
\text { organizations) }\end{array}$ \\
\hline $\begin{array}{l}\text { Boundary object } \\
\text { handler }\end{array}$ & $\begin{array}{l}\text { Recognizes opportunities for the creation or adaptation of boundary objects to acquire } \\
\text { larger value in cross-boundary interactions }\end{array}$ \\
\hline Interim manager & $\begin{array}{l}\text { A marginal actor who can 'wear many different hats', allowing them to mediate between } \\
\text { different social and political worlds }\end{array}$ \\
\hline $\begin{array}{l}\text { Coupler and } \\
\text { decoupler }\end{array}$ & $\begin{array}{l}\text { Articulating the processes and results of urban experiments in terms of either being } \\
\text { situated (i.e., coupled) within a specific urban context/scenario, or decoupled from the } \\
\text { urban context and generalizable }\end{array}$ \\
\hline Urban activist & $\begin{array}{l}\text { Agents of transformation, privileging concrete over communicative action, defending } \\
\text { opportunities that ensure citizens have control over urban spaces }\end{array}$ \\
\hline Warden of a city & $\begin{array}{l}\text { Coordinate innovation initiatives to avoid excessive fragmentation and enable coherent } \\
\text { growth towards a shared urban identity }\end{array}$ \\
\hline
\end{tabular}

However, actually existing planning education and practice has not yet caught up with planning

theory in this regard. In a recent article in the American Planning Journal (Schweitzer \& Afzalan, 2017), the authors noted that the professional body of planners in the US, the American Institute of Certified Planners (AICP), had yet to adopt a formal stance on open data within its code of ethics. The authors go on to stress how imperative it is that planners adopt a clear ethic around open data and smart urbanism in their professional codes of practice, including: 1) curating and communicate open data in a user-friendly way for public use; 2) pushing for code and data used in public decision-making to be made open and available for scrutiny; 3) advocating for public (as opposed to private) ownership of the data collected, and; 4) being responsible stewards of all citizen data we encounter in our professional practices (Schweitzer \& Afzalan, 2017).

According to these authors, the time is now for planners to seriously contend with how our field will respond to the opportunities and challenges that will arrive with smart cities, big 
data, governance by algorithm, urban sensors and artificial intelligence (Centre for Ethics, 2018b). However, the relative newness of smart cities projects has meant that the planning profession is still grappling with how existing practices might need to be adapted to tackle the challenges of planning in the smart city. Furthermore, the Professional Standards Board (2013) the accrediting body for Canadian planning schools - does not include "smart cities" (or related terms) in its list of Functional Competencies for evaluating programs. Overall, planning education does not equip future planners with the knowledge needed to practice in a world where urban informatics will soon be ubiquitous (French, Barchers, \& Zhang, 2017). 


\subsection{Approach}

To date, the majority of resources discussing smart cities have been produced from an industry perspective and consequently act equally as advertisements for technology products and services (Center for Urban Innovation, 2015; Korngold, Lemos, \& Rohwer, 2017). There is a gap in terms of educational resources aimed at spurring dialogue around what is at stake for planning professionals in a world where big data shapes our cities.

\subsection{Discussion Guide}

Through an action research approach involving a review of recent academic and popular literature on smart cities, specifically on frameworks to meaningfully incorporate grassroots, citizen input, I have created a discussion guide (Appendix B) to teach planners about key concepts in smart cities, including big data and urban informatics, as well as the broader implications for planning practice.

Partially inspired by a list of questions crowdsourced from a group ${ }^{2}$ of academics and thinkers working in areas such as open data, privacy, planning, and governance (Wylie, 2017), the objective of this discussion guide is to bring these critical questions to the forefront of planning around smart cities projects and signal to planners that they can (indeed must) participate in discussions and share their knowledge even though they may have no background in computer science or engineering (Centre for Ethics, 2018b). Scott (1998, p. 5) noted ${ }^{3}$ that, "an incapacitated civil society provides the leveled social terrain on which to build.” The principle

\footnotetext{
${ }^{2}$ The supervisor of this major research project, Dr. Pamela Robinson, was an original contributor to this list of questions.

${ }^{3}$ Scott wrote this with regards to large-scale, modernist social engineering programs, but the sentiment is applicable nonetheless, in the author's opinion.
} 
underlying this project is that a strong civil society - including a deliberate, reflective urban planning profession - is absolutely essential to shaping our future cities, however 'smart' they end up becoming. This endeavour was further informed by my work on a studio project ${ }^{4}$ for the City of Toronto's Draft Automated Vehicle Tactical Plan 2019-2021, involving the creation of similar educational materials to give stakeholders the background knowledge to meaningfully participate in a series of workshops. The driving force of these consultations - the imminent arrival of automated vehicles on city streets and lack of municipal preparedness - has a great deal of resonance with this major research project.

The discussion booklet was peer-reviewed for accuracy ${ }^{5}$, and the resulting feedback was incorporated into the final deliverable. It is intended to be a high-level, open-ended resource to inspire further interest and research into the details of smart cities projects, rather than focusing on the particular details of one smart technology or another.

The guide consists of the following sections:

- Introduction

- This section immediately informs the reader why they, as a planner, ought to be concerned about smart cities: Big data and smart city technology is already here and poised to have an even greater impact on our cities and planning practice.

- What is a smart city?

- This section outlines several specific smart technologies and their applications to various urban systems, as an illustration of proposed benefits. In contrast to vague

\footnotetext{
${ }^{4}$ This project was supervised by Dr. Matthias Sweet and the project team included: Élyse Comeau, Kasia Kmieć, Tyler Olsen, Safiyyah Saleh, James Schofield, and Josie Tavares.

${ }^{5}$ Peer-review was carried out by Bianca Wylie, a local public engagement and open data expert.
} 
claims made in many guides produced by smart city vendors or consultants, this section is limited to those interventions for which there is evidence.

- What is big data?

- Since data underlies the entire premise of a smart city, this section aims to introduce some key concepts to readers such as big data, the 'Internet of Things', algorithms, and dashboards. It also outlines (in a simplified way) how data is collected and assimilated into smart city technology.

- Why does this matter to planners?

- This section synthesizes many of the concerns described in Section 2.3 into a set of four broad points that will hopefully resonate with planning audience: 1) The huge amounts of raw, unfiltered data generated in the smart city are useless to most users; 2) Decision-making and service delivery will increasingly be driven by big data and algorithms, yet we can't easily 'look inside' and question how they work; 3) Big data, while less visible than the built environment, will profoundly change the urban experience, and; 4) racking people's behaviour in public spaces, collecting and storing their data raises serious ethical questions around privacy and consent.

- What questions should planners ask?

- This section highlights many of the high-level questions raised in the list of questions for Sidewalk Labs (Wylie, 2017) as a way of stimulating critical dialogue.

- What can planners do? 
- These are actions which skew more towards advocacy roles (for privacy and open data) and public education, but provide suggestions for specific roles for planners in certain sectors.

- Sources/Further Resources

- This section allows readers to track original sources and provides a starting point for further exploration with a list of organizations engaged in work on the themes presented in the guide, as well as books and reports that may be of interest.

\subsection{Using the discussion guide in planning practice}

As it stands, much of the uncertainty around big data and smart city technology is a product of lack of information and transparency about processes. For example, the Sidewalk Toronto project has been roundly criticized for its failure to release specific details on if or how collected data will be used commercially (Wylie, 2018). As Robinson and Johnson (2016) have noted, the release of huge quantities of formerly restricted datasets has presented both an opportunity to drastically increase transparency within government but also a challenge in that average citizens may lack the technical knowledge to meaningfully engage with this data. Civic hackathons may be one solution to this problem, being "time-limited events gather[ing] tech enthusiasts, government workers and interested citizens, in a collaborative environment to apply government open data in developing software applications that address issues of shared civic importance" (Robinson \& Johnson, 2016, p. 65). While these events present a novel venue for citizen engagement, they also raise questions: For example, is technological expertise a prerequisite for participation? 
The Ontario Professional Planners Institute (OPPI) Professional Code of Practice states that planners have a responsibility to "provide full, clear and accurate information on planning matters" (OPPI, 2018). In an era of big data, this means being proactive, readying datasets with public use in mind, and anticipating how grassroots planning efforts might use open data. The role of public libraries in fostering this capacity as "civic infomediaries" has been explored by Robinson and Ward Mather (2017) and offers a potential way forward. Public libraries, the authors argue, as an already-existing infrastructure with roots across the urban area are uniquely positioned to use their reach to bridge the open data divide by providing space and barrier-free access to technologies. In this view, public institutions such as libraries could be reimagined as incubators of grassroots, citizen-generated smart city solutions. Not only is there the opportunity for municipal planning departments to forge new partnerships with public libraries, but planners can follow the example of library professionals who have adapted their mission of providing equal access to information in the era of big data. It is this latter goal that this guide aims to facilitate.

\subsubsection{Use in development approvals process}

The Sidewalk Toronto project may prove to be a test case for the way in which subsequent smart city developments are handled by current development approvals processes. Mapping the highlevel principles from the discussion guide onto the City of Toronto's development approvals process flowchart (Figure 1) illustrates how they might be operationalized by planners in public, private, and not-for-profit sectors becoming involved at different points.

Public sectors planners (e.g., City staff) are in a position to offer advice to proponents of smart city developments as soon as an application is brought forward, during the pre-application consultation, as well as later steps in the process. Developers should be advised to submit a plan 
outlining how they will address data privacy and security as well as transparency and inclusivity. Ideally, this would be enshrined as a requirement for a complete development application by City Council. Essentially, planners working within the government would adopt an equity planning approach (Albrechts, 2016).

While private sector planners offering consulting services to clients are in an understandably more sensitive position and need to exercise tact with regards to what advice they give - after all, they want to keep their clients content - this discussion guide can still be useful for their practice. Private sector consultants have the opportunity to frame their recommendations in terms of their clients' best interest - that is, for their application to be met with public support as well as municipal approval, it would be advantageous for clients to anticipate concerns (e.g., around data privacy, exclusion, surveillance, participation) from the community and do their best to mitigate them. An additional motivation is that, once smart city developments become more commonplace and the public savvier to the issues associated with them, planning consultant firms with a track record of helping their clients successfully navigate these concerns may see an increase in business.

Finally, planners working outside the system (e.g., non-governmental organizations, community-based organizations, etc.) can afford to adopt a more radical approach, pushing from the margins and focusing on tackling structural inequalities that might be exacerbated by smart city developments. The discussion guide I have developed could act as a resource which these organizations could use in community planning clinics or educational workshops, giving community members the vocabulary to effectively articulate their concerns during the public consultation phase of a development application. Looking back to the Sidewalk Toronto project, not-for-profit organizations can challenge the process itself and the conflict-of-interest present 
with a potential vendor of smart city technology leading the development of a precinct plan (Centre for Ethics, 2018a). These organizations are positioned to be able to interrogate the need for more data collection in the first place and create the space for essential critical dialogue.

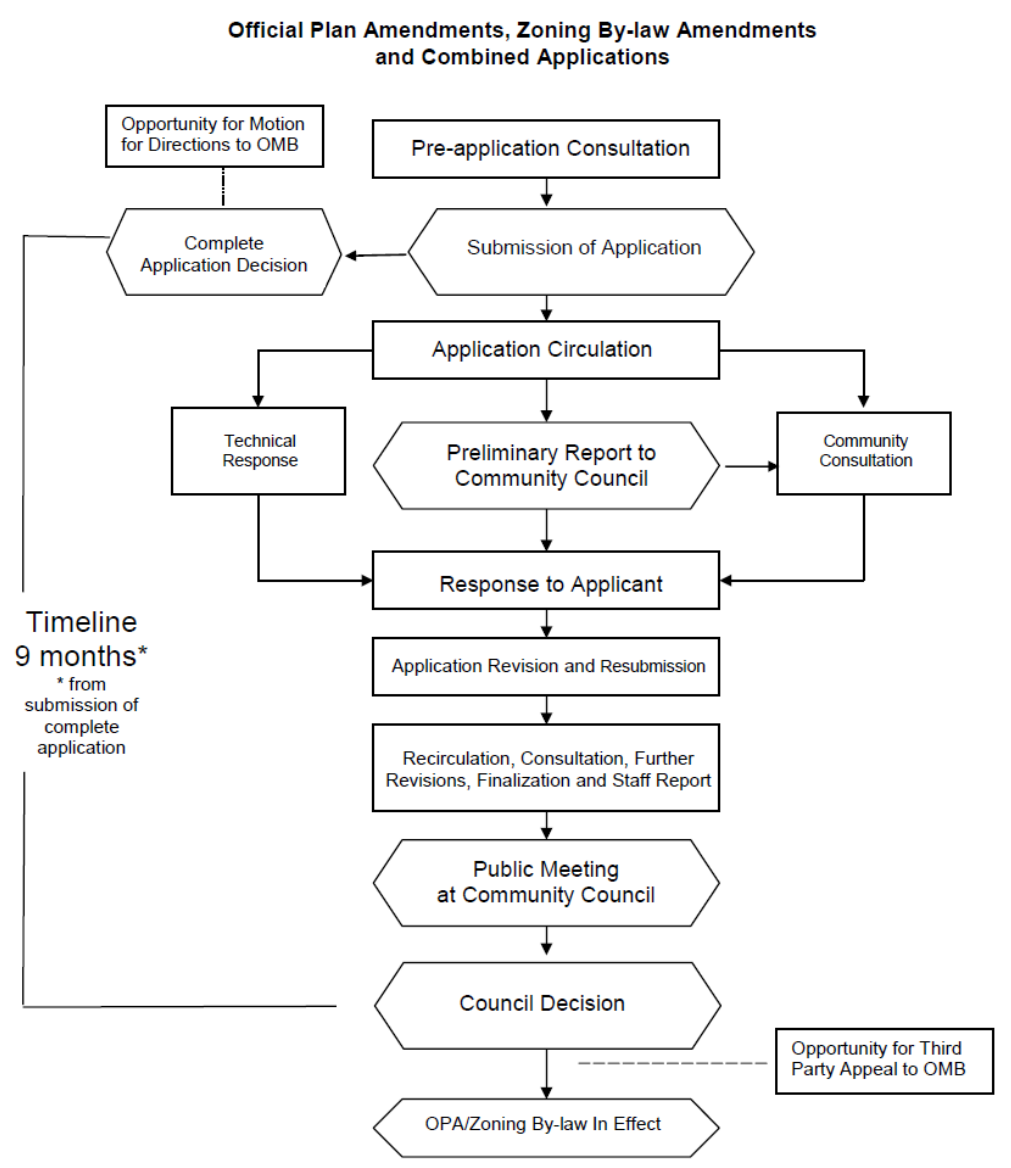

Figure 1: City of Toronto Official Plan and Zoning By-law Amendment Process Flowchart

\subsubsection{Further possibilities for dissemination}

In order to ensure that this research reaches as wide of an audience as possible, there are several avenues of dissemination I will pursue. First, I will distribute the final version of the discussion guide to open data and digital justice networks within Toronto with the aim of introducing them to this resource and catalyzing further collaboration. In conjunction with Dr. Pamela Robinson, I will also endeavour to reach the professional planning community by writing and submitting an article to the OPPI Journal outlining key points from this major research project and the 
discussion guide. Finally, I will pursue opportunities to engage with fellow researchers in this area through participating in webinars (e.g., Geothink\&Learn webinar series) and professional conferences (e.g., OPPI Conference). 


\subsection{Next Steps}

This research project and discussion guide should not be considered an end in themselves, but rather a jumping-off point for addressing a new, challenging area for urban planning professionals. There are several future directions that should be pursued in the short and medium term to carry forward the momentum of this project.

First, as mentioned previously, the discussion guide I have developed is a preliminary step towards articulating the challenges and opportunities for planners in an accessible way. Future iterations of this guide will benefit immensely from knowledge contributed by working planners across public, private, and not-for-profit sectors - perhaps eventually warranting a separate guide tailored to each sector. Related to this objective is the creation of a public-facing, citizen-oriented guide to understanding and self-advocating in the face of smart city developments. An excellent precedent to look to in this regard is the work of the Center for Urban Pedagogy ${ }^{6}$, which engages artists and designers to create easy-to-understand introductions to complex planning issues with the goal of increasing civic engagement. Drawing upon local talent and expertise will ensure a higher degree of community buy-in to this project and its objectives.

In the medium to long term, planning programs across Canada ought to make smart cities a part of their curriculum. As mentioned in Section 2.5, planning curricula across Canada are required to address a core set of knowledge bases and competencies, of which smart cities or

\footnotetext{
${ }^{6}$ From their website, The Center for Urban Pedagogy is a New York City based nonprofit organization that "uses the power of design and art to increase meaningful civic engagement. CUP collaborates with designers, educators, advocates, students, and communities to make educational tools that demystify complex policy and planning issues." (http://welcometocup.org/)
} 
data-driven urbanism are not an explicit component. Therefore, the only exposure many students are likely to have to issues associated with smart cities may come from special topics courses individual instructors's decisions to include this material. Urban informatics is not just a land use planning issue; it cuts across many facets of planning, from professional ethics to theory to law to sustainability, and should therefore be integrated throughout the curriculum. Rather than waiting for individual programs to change on their own timeline, such a realignment of curricular focus could be precipitated by the Professional Standards Board altering its accreditation requirements to require future planners be prepared with the knowledge to address the challenges of professional practice in the smart city. Professional bodies, such as the Ontario Professional Planners Institute, also have a role to play. Registered Professional Planners are required to complete 18 hours of Continuous Professional Learning on an annual basis, providing an avenue through which to educate practicing planners about smart city technology once they have left university.

By taking these steps, it is hoped that planning professionals will be able to best position themselves to shape smart city investments and leverage them to build a more equitable and inclusive city. Ultimately, the planning profession must position itself to make sure that technology is not the sole driver of change. With regards to smart city planning policy, this means being more deliberate, assessing alternatives, and making informed determinations about what works, what does not work and for whom. Constellations of sensors embedded in sidewalks and buildings may have the ability to collect and analyze vast amounts of data, leading to great potential for these technologies to optimize service delivery and produce operational efficiencies over the long run. But as Hollands (2013, p. 13) put it, "the real smart city has to begin to think with its collective social and political brain, rather than through its 'technological tools"' Planners 
will need to push back against the post-conflict, post-political discourse which says smart city solutions render our field of practice obsolete. On the contrary, urban space has always been and will continue to be a contested domain in which public and private interests compete. Regardless of how the smart city eventually takes shape, planners will be needed more than ever; it is up to us to decide how we will act. 


\section{References}

Albrechts, L. (2016). Strategic Planning as Governance of Long-Lasting Transformative Practices. In G. Concilio \& F. Rizzo (Eds.), Human Smart Cities: rethinking the interplay between design and planning (pp. 3-60). https://doi.org/10.1007/978-3-319-33024-2

Bélissent, J. (2010). Getting clever about smart cities: New opportunities require new business models. Forrester Research, Inc. Retrieved from http://groups.open.org.nz/groups/ninja$\underline{\text { talk/files/f/19710-2010-11- }}$ 04T092134Z/getting_clever_about_smart_cities_new_opportunities.pdf

Bloomberg News. (2017, May 8). Google-parent Alphabet applies to turn 12-acres of Toronto's waterfront into connected high-tech city: sources. Financial Post. Retrieved from http://business.financialpost.com/technology/google-parent-alphabet-applies-to-turn-12acres-of-torontos-waterfront-into-connected-high-tech-city-sources/wcm/c41d5216-de89$\underline{42 \mathrm{cf}-8 \mathrm{a} 27-7 \mathrm{a} 36 \mathrm{f} 4181 \mathrm{ecc}}$

Canadian Council for Public-Private Partnerships. (2011). Public-Private Partnerships: A Guide for Municipalities, 1-74. Retrieved from http://www.p3canada.ca/ /media/english/resources-library/files/p3 guide for municipalities.pdf

Caprotti, F., \& Cowley, R. (2016). Interrogating urban experiments. Urban Geography, 0(0), 110. https://doi.org/10.1080/02723638.2016.1265870

Cardullo, P., \& Kitchin, R. (2017a). Being a “citizen” in the smart city: Up and down the scaffold of smart citizen participation (The Programmable City Working Paper No. 30). Retrieved from https://osf.io/preprints/socarxiv/v24jn

Cardullo, P., \& Kitchin, R. (2017b). Living Labs, vacancy, and gentrification (The Programmable 
City Working Paper No. 28). Retrieved from https://osf.io/preprints/socarxiv/waq2e

Center for Urban Innovation. (2015). Smart cities financing guide: Expert analysis of 28 municipal finance tools for city leaders investing in the future.

Centre for Ethics. (2018a). Ethics in the City: Bianca Wylie, Countering the Digital Consensus [Video file]. Retrieved from https://youtu.be/XG_AxMuI2do

Centre for Ethics. (2018b). Ethics in the City: Pamela Robinson, Canadian Smart Cities: Defining the Public Good [Video file]. Retrieved from https://youtu.be/XTy7fRAHu7I Cities for People. (2018, February 16). Streets and Sidewalks in Alphabet's City. Medium. Retrieved from https://medium.com/cities-for-people/streets-and-sidewalks-in-alphabetscity-7200fb $8 \mathrm{db} 05 \mathrm{~b}$

Concilio, G. (2016). Urban Living Labs: Opportunities in and for Planning. In G. Concilio \& F. Rizzo (Eds.), Human Smart Cities: rethinking the interplay between design and planning. Springer.

Cosgrave, E., Arbuthnot, K., \& Tryfonas, T. (2013). Living labs, innovation districts and information marketplaces: A systems approach for smart cities. Procedia Computer Science, 16(Cser 13), 668-677. https://doi.org/10.1016/j.procs.2013.01.070

Cruz, C. O., \& Sarmento, J. M. (2017). Public-Private Partnerships and Smart Cities. Network Industries Quarterly, 19(3), 3-5. Retrieved from https://mir.epfl.ch/files/content/sites/mir/files/Newsletter/Vol\%2019,\%20No\%203,\%202017 NIQ\%20Vol\%2019\%20-\%20Issue\%203\%20-\%202017\%20-\%20Part\%201.pdf

de Cordova, S. F. (2018). Smart cities are changing: The rise of the city as a public-private partnership service model, 1-6. Retrieved from https://medium.com/@sfdecordova/smartcities-are-changing-93251a46884a 
Dodge, M., \& Kitchin, R. (2005). Code and the Transduction of Space. Annals of the Association of American Geographers, 95(1), 162-180. https://doi.org/10.1111/j.1467-

\section{$\underline{8306.2005 .00454 . x}$}

Eubanks, V. (2017). Automating inequality: How high-tech tools profile, police, and punish the poor. New York: St. Martin's Press.

French, S. P., Barchers, C., \& Zhang, W. (2017). How should urban planners be trained to handle big data? In P. (Vonu) Thakuriah, N. Tilahun, \& M. Zellner (Eds.), Seeing Cities Through Big Data (pp. 209-217). Cham, Switzerland: Springer.

Grossi, G., \& Pianezzi, D. (2017). Smart cities: Utopia or neoliberal ideology? Cities, 69(December 2016), 79-85. https://doi.org/10.1016/j.cities.2017.07.012

Halpern, O., Lecavalier, J., Calvillo, N., \& Pietsch, W. (2012). Test-Bed Urbanism. Public Culture, 25(2), 272-306. https://doi.org/10.1215/08992363-2020602

Halpern, O., \& Günel, G. (2017). FCJ-215 Demoing unto Death: Smart Cities, Environment, and Preemptive Hope. The Fibreculture Journal, (29). https://doi.org/10.15307/fcj.29.215.2017

Harvey, D. (1989). From Managerialism to Entrepreneurialism: The Transformation in Urban Governance in Late Capitalism. Geografiska Annaler. Series B, Human Geography, 71(1),

\section{3. https://doi.org/10.2307/490503}

Hollands, R. G. (2008). Will the real smart city please stand up? Intelligent, progressive or entrepreneurial? City, 12(3), 303-320. https://doi.org/10.1080/13604810802479126

Hollands, R. G. (2013). Is an "alternative" smart city possible? Critically revisiting the smart city debate. Smart Urbanism: Utopian Vision or False Dawn?

Hulchanski, J. D. (2010). The Three Cities Within Toronto: Income Polarization Among Toronto's Neighbourhoods, 1970-2005. Toronto: Cities Centre, University of Toronto. 
International Association for Public Participation (IAP2). (2014). IAP2 Spectrum of Participation. Retrieved from http://www.iap2.org/resource/resmgr/foundations_course/IAP2_P2 Spectrum_FINAL.pdf

Kitchen, H. (2000). Municipal Revenue and Expenditure Issues in Canada.

Kitchin, R. (2014a). The data revolution: Big data, open data, data infrastructures \& their consequences. Los Angeles, CA: SAGE.

Kitchin, R. (2014b). The real-time city? Big data and smart urbanism. GeoJournal, 79(1), 1-14. https://doi.org/10.1007/s10708-013-9516-8

Kitchin, R. (2016a). Thinking critically about and researching algorithms. Information, Communication \& Society, 20(1), 14-29. https://doi.org/10.1080/1369118X.2016.1154087

Kitchin, R. (2016b). Urban big data. Retrieved from https://www.theplanner.co.uk/features/urban-big-data

Kitchin, R., Coletta, C., Evans, L., Heaphy, L., \& Mac Donncha, D. (2017). Smart cities, urban technocrats, epistemic communities and advocacy coalitions (The Programmable City Working Paper No. 26). Retrieved from https://osf.io/preprints/socarxiv/rxk4r/

Kitchin, R., Lauriault, T. P., \& McArdle, G. (2015a). Knowing and governing cities through urban indicators, city benchmarking and real-time dashboards. Regional Studies, Regional Science, 2(1), 6-28. https://doi.org/10.1080/21681376.2014.983149

Kitchin, R., Lauriault, T. P., \& McArdle, G. (2015b). Response: Urban indicators and dashboards: Epistemology, contradictions and power/knowledge. Regional Studies, Regional Science, 2(1), 43-45. https://doi.org/10.1080/21681376.2014.991485

Kitchin, R., Lauriault, T. P., \& Wilson, M. W. (Eds.). (2017). Understanding spatial media. Los Angeles, CA: SAGE. 
Korngold, D., Lemos, M., \& Rohwer, M. (2017). Smart Cities for All: A Vision for an Inclusive, Accessible Urban Future. Dallas. Retrieved from http://smartcities4all.org/wpcontent/uploads/2017/06/Smart-Cities-for-All-A-Vision-for-an-Inclusive-Accessible-UrbanFutur...-min.pdf

Kummitha, R. K. R., \& Crutzen, N. (2017). How do we understand smart cities? An evolutionary perspective. Cities, 67(March), 43-52. https://doi.org/10.1016/j.cities.2017.04.010

Lorinc, J. (2017, November). Let's talk about Sidewalk Labs' \$50 million investment. Spacing. Retrieved from http://spacing.ca/toronto/2017/11/06/lorinc-lets-talk-about-sidewalk-labs$\underline{\text { 50-million-investment/ }}$

Luque-Ayala, A., \& Marvin, S. (2015). Developing a critical understanding of smart urbanism? Urban Studies, 52(12), 2105-2116. https://doi.org/10.1177/0042098015577319

Luque-Ayala, A., \& Marvin, S. (2016). The maintenance of urban circulation: An operational logic of infrastructural control. Environment and Planning D: Society and Space, 34(2), 191-208. https://doi.org/10.1177/0263775815611422

McAllister, M. L. (2004). Governing ourselves? The politics of Canadian communities. Vancouver, B.C.: UBC Press.

McFarlane, C., \& Söderström, O. (2017). On alternative smart cities. City, 1-17. https://doi.org/10.1080/13604813.2017.1327166

Murakami Wood, D. (2017). Spatial profiling, sorting and prediction. In R. Kitchin, T. P. Lauriault, \& M. W. Wilson (Eds.), Understanding spatial media (pp. 225-234). Los Angeles, CA: SAGE Publications.

Ontario Professional Planners Institute. (2018). Professional Code of Practice. Retrieved from http://ontarioplanners.ca/Knowledge-Centre/Professional-Code-of-Practice 
Pasquale, F. (2015). Black Box Society: The Secret Algorithms that Control Money and Information. Cambridge, Mass.: Harvard University Press.

Professional Standards Board. (2013). Accreditation Standard - New Planning Degree Programs. Retrieved from http://www.psbplanningcanada.ca/UNIVERSTYACCREDITATION/index.php

Robinson, P. J., \& Johnson, P. A. (2016). Civic hackathons: new terrain for local governmentcitizen interaction? Urban Planning, 1(2), 65-74. https://doi.org/10.17645/up.v1i2.627

Robinson, P. J., \& Ward Mather, L. (2017). Open Data Community Maturity: Libraries as Civic Infomediaries. Journal of the Urban and Regional Information Systems Association, 28, 3138. http://www.urisa.org/clientuploads/directory/Documents/Journal/Vol28_final.pdf

Sadoway, D., \& Shekhar, S. (2014). (Re)Prioritizing Citizens in Smart Cities Governance: Examples of Smart Citizenship from Urban India. The Journal of Community Informatics, 10(3), 1-15. Retrieved from http://www.ci-journal.net/index.php/ciej/article/view/1179

Sandercock, L. (2003). Cosmopolis II: mongrel cities of the 21st century. London: Continuum. Schuler, D. (2016). Smart Cities + Smart Citizens = Civic Intelligence? In G. Concilio \& F. Rizzo (Eds.), Human Smart Cities: Rethinking the Interplay between Design and Planning (pp. 41-60). Cham, Switzerland: Springer International Publishing.

\section{https://doi.org/10.1007/978-3-319-33024-2_3}

Schweitzer, L. A., \& Afzalan, N. (2017). 09 F9 1102 9D 74 E3 5B D8 4156 C5 635688 C0: Four Reasons Why AICP Needs an Open Data Ethic. Journal of the American Planning Association, 83(2), 161-167. https://doi.org/10.1080/01944363.2017.1290495

Scott, J. C. (1998). Seeing Like a State: How Certain Schemes to Improve the Human Condition Have Failed. New Haven, CT: Yale University Press. 
Sidewalk Labs. (2017). Project Vision. Toronto. Retrieved from https://sidewalktoronto.ca/wpcontent/uploads/2017/10/Sidewalk-Labs-Vision-Sections-of-RFP-Submission.pdf

Sidewalk Toronto. (2018). Public engagement plan. Retrieved from

https://sidewalktoronto.ca/wp-content/uploads/2018/02/Sidewalk-Toronto-Public-

\section{Engagement-Plan.pdf}

Walravens, N., \& Ballon, P. (2013). Platform business models for smart cities: From control and value to governance and public value. IEEE Communications Magazine, 51(6), 72-79. https://doi.org/10.1109/MCOM.2013.6525598

Waterfront Toronto. (2017). Request for Proposals: Innovation and Funding Partner for the Quayside Development Opportunity. Toronto.

Wiig, A. (2016). The empty rhetoric of the smart city: from digital inclusion to economic promotion in Philadelphia. Urban Geography, 37(4), 535-553. https://doi.org/10.1080/02723638.2015.1065686

Wylie, B. (2017). Civic Tech : A list of questions we'd like Sidewalk Labs to answer. Torontoist. Retrieved from https://torontoist.com/2017/10/civic-tech-list-questions-wed-like-sidewalklabs-answer/

Wylie, B. (2018, November 8). Think hard before handing tech firms the rights to our cities' data. The Huffington Post. Retrieved from http://www.huffingtonpost.ca/bianca-wylie/thinkhard-before-handing-tech-firms-the-rights-to-our-cities-data_a 23270793/

Yuan, X.-X., \& Zhang, J. (2016). Understanding the Effect of Public-Private Partnerships on Innovation in Canadian Infrastructure Projects. Toronto.

Zuckerman, E. (2013). Beyond the crisis in civics: Notes from my 2013 DML talk. Retrieved from http://www.ethanzuckerman.com/blog/2013/03/26/beyond-the-crisis-in-civics-notes- 
from-my-2013-dml-talk/ 


\section{Appendix A: Smart City Technologies and their Applications to City Systems}

Table A-1: Smart Technologies and their Applications to City Systems (adapted from Bélissent, 2010, p. 9)

\begin{tabular}{|c|c|}
\hline City system & Examples of smart solutions \\
\hline Transportation & $\begin{array}{l}\text { Smart transportation solutions use sensors and analytics to predict the arrival of a bus or } \\
\text { train and notify passengers via SMS or through information boards at city bus and train } \\
\text { stations. Parking information is also available in response to an SMS query or information } \\
\text { signs advertising free parking spaces using sensors to detect available spaces. Payment may } \\
\text { be made via SMS. Municipal fleet management solutions use onboard sensors in vehicles to } \\
\text { detect and notify drivers or fleet owners when there is a problem with the vehicle, if there is } \\
\text { an accident, or when maintenance procedures are needed. }\end{array}$ \\
\hline Healthcare & $\begin{array}{l}\text { Smart healthcare solutions include telemedicine applications, electronics records } \\
\text { management, health information exchanges, hospital and clinic asset management, and } \\
\text { supply chain optimization. Patients can be fitted with ID bracelets that include GPS } \\
\text { capabilities that track a patient's location, medication administration, and medical } \\
\text { condition. Data from remote diagnostics equipment in a patient's home can monitor the } \\
\text { status of vital signs, blood pressure, and glucose levels and can be used as an alternative to } \\
\text { visiting a doctor's office. There are also remote monitoring systems for disabled, } \\
\text { chronically ill, or elderly patients. }\end{array}$ \\
\hline Education & $\begin{array}{l}\text { Smart education solutions range from eLearning to connected campuses. Learning } \\
\text { solutions focus on increased access to educational content and improved collaboration } \\
\text { among students and faculty through connectivity, content management, and unified } \\
\text { communication technologies. Large universities also leverage broadband, Wi-Fi, sensors, } \\
\text { and analytics to improve the efficiency and cost-effectiveness of university services from } \\
\text { campus transportation to public safety to administration. }\end{array}$ \\
\hline $\begin{array}{l}\text { Public safety and } \\
\text { security }\end{array}$ & $\begin{array}{l}\text { Smart public safety solutions use sensor-activated video surveillance cameras, video } \\
\text { analytics, and workflow to identify and route suspicious or anomalous observations to the } \\
\text { appropriate authorities. Enhanced } 911 \text { systems automatically identify a caller's location } \\
\text { either through the fixed telephone location, or via cell triangulation or GPS in the case of } \\
\text { mobile calls. }\end{array}$ \\
\hline $\begin{array}{l}\text { Building } \\
\text { management }\end{array}$ & $\begin{array}{l}\text { Smart building management solutions use smart meters, monitoring devices, and sensors } \\
\text { to connect heating, air-conditioning, lighting, security systems, and other appliances in } \\
\text { homes and businesses, enabling users to better track and control use of electricity and } \\
\text { water. }\end{array}$ \\
\hline $\begin{array}{l}\text { City } \\
\text { administration }\end{array}$ & $\begin{array}{l}\text { Smart city administration solutions facilitate the automation of city processes, from } \\
\text { reporting of complaints to registration of a business or renewal of a driver's license. Rules } \\
\text { engines and automated workflows streamline processes and facilitate interactions with city } \\
\text { administration. }\end{array}$ \\
\hline $\begin{array}{l}\text { Waste } \\
\text { management }\end{array}$ & $\begin{array}{l}\text { Smart waste management solutions use sensors (e.g., capacity sensors to trigger waste } \\
\text { removal, electronic noses to detect toxicity in landfills), automatic notification, and } \\
\text { collaboration among local authorities to improve the efficiency of waste collection and } \\
\text { treatment. }\end{array}$ \\
\hline
\end{tabular}




\section{Appendix B: Discussion Guide}

Discussion guide attached on following page 


\section{Whose Smart City? Creating more open and inclusive urban digital experiments}

\section{A discussion guide for planners}

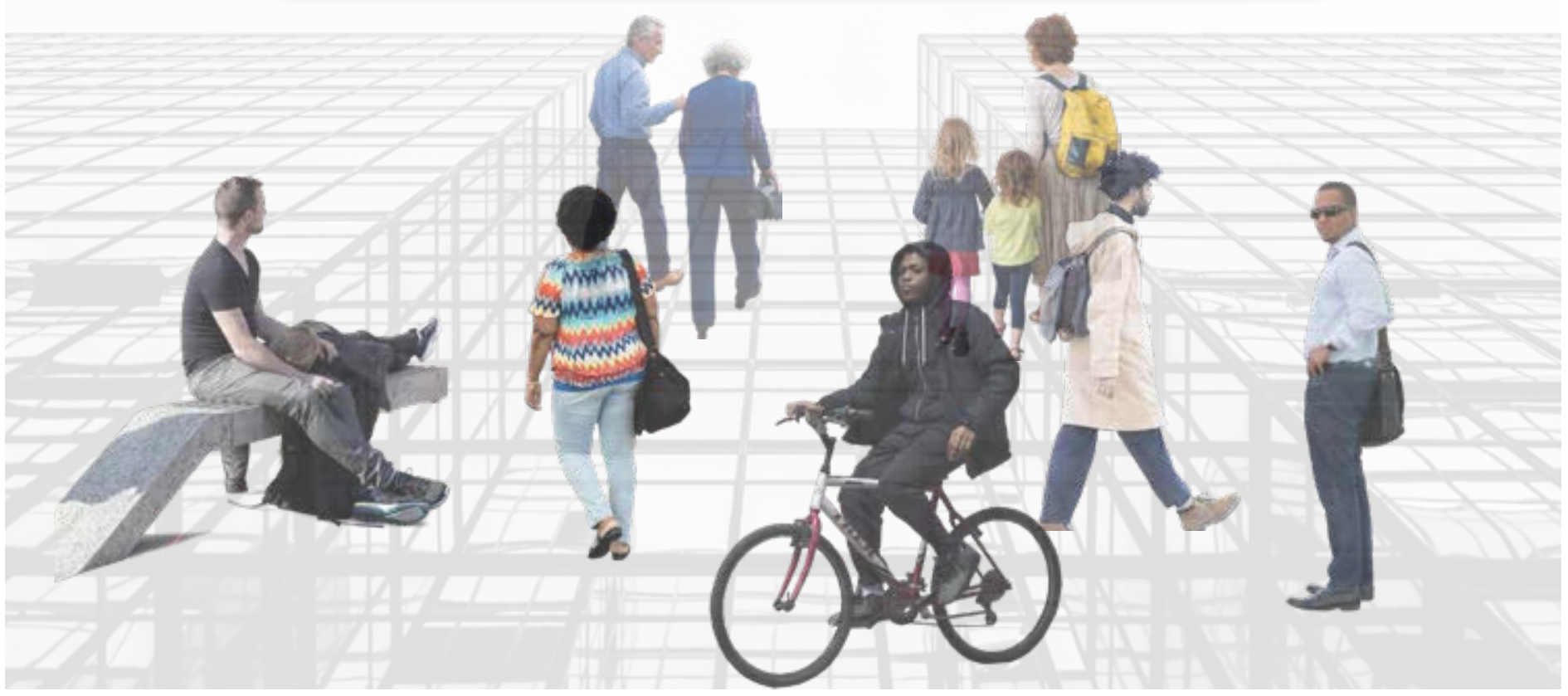




\section{Who is this guide for?}

As urban planners, we may have heard about 'smart cities', but haven't fully considered what this means for our practice. Maybe it sounds too complex, or just not in our professional domain and best left to tech experts.

However as we'll see, the combination of big data and smart city technology what we'll call 'urban informatics' in this guide- is already here and has major implications for planners. The time is now for us to reimagine our role in light of the challenges raised by this technology. Instead of allowing the technology to guide us, we need to guide the technology and ask: Do we actually need to implement this technology or collect this data? Will this lead to the best outcomes for my community?

This guide is intended as a brief introduction for all planning professionals, whether we're working in the public, private, or not-for-profit sector, to equip us with the basic knowledge and principles to guide our work as big data and smart city technology arrive in our communities.

It's not, however, meant to be authoritative. Its aim is also to inspire discussion, collaboration, and knowledge-sharing among planners. If you read something you don't quite understand or agree with, your feedback would be greatly valued and will help improve future versions of this guide. 


\section{What is a 'Smart City'?}

According to proponents, urban big data and the smart city technologies supporting will allow city agencies and departments to better coordinate by breaking down silos between them. Some of the proposed benefits are shown below:
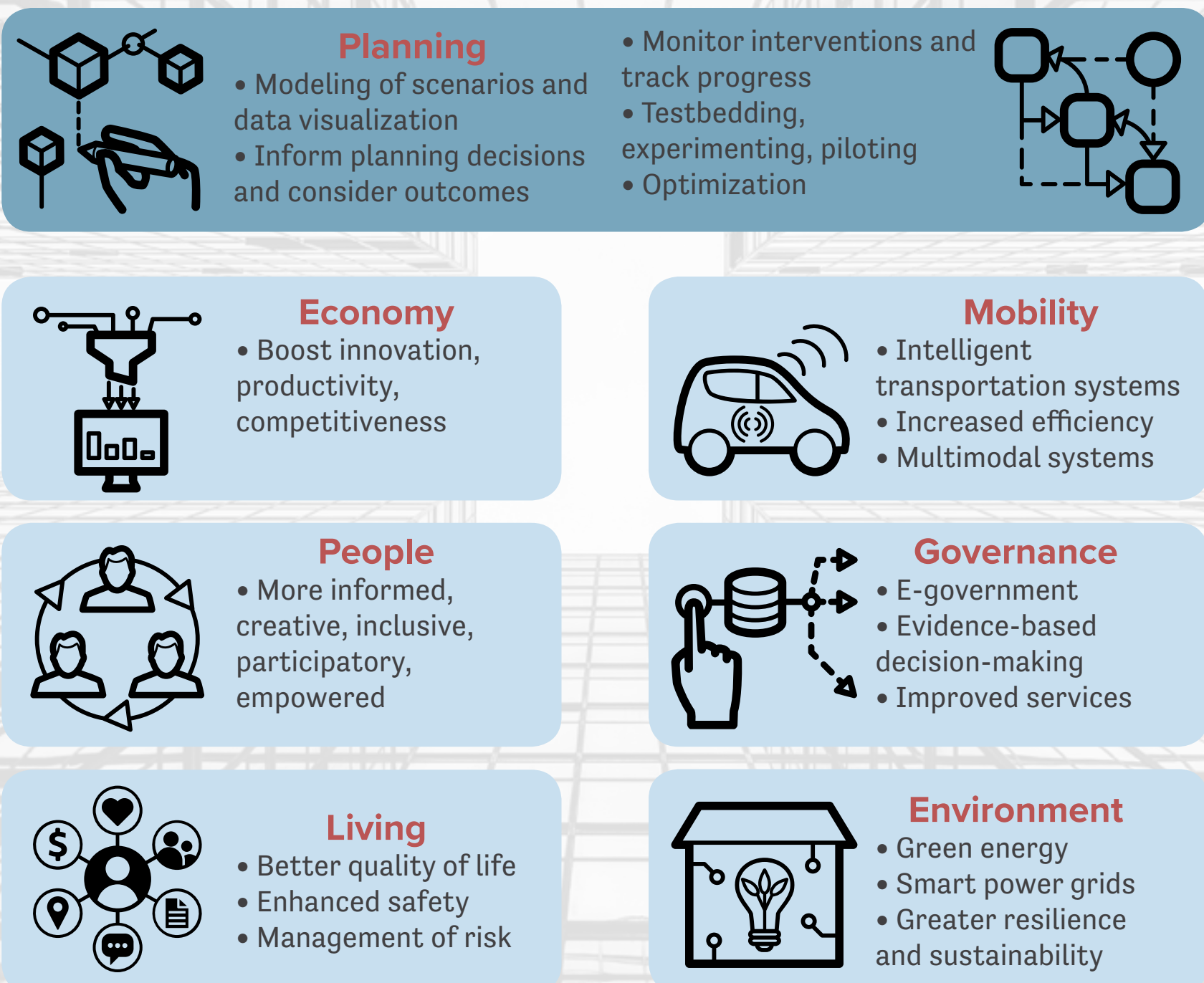


\section{What is Big Data?}

Big data essentially means what it sounds like - lots and lots of data. The biggest difference between big data and regular data is that huge increases in computing power have made easier to process these mountains of data points. It's important to note that the data itself is only as smart as what humans do with it. For example, a system designed to handle location-based, or real-time data could allow a planner to see a fine-grained, real-time picture of city systems and services. Assuming the data inputs are reasonably high quality, we could see patterns of travel or pollution across times of the day, days of the week, and seasons, and for all points on a network (for example, intersections, bus stops, sensor locations) ${ }^{2}$.

\section{How is this data collected?}

The Internet of Things - including digital cameras, sensors, transponders, meters, actuators, GPS, and other technology all connected via the Internet - measures and tracks current conditions on the ground. Besides these, user-generated data from smartphone apps, sharing economy platforms (e.g., Uber, Yelp, etc.) and (eventually) automated vehicles generate a range of location, movement and activity data.

\section{Where does all the data come from?}

- Utility companies (use of electricity, gas, water)

- Transportation providers (location/movement, travel flow);

- Mobile phone carriers (location/movement, app use, behaviour)

- Travel/accommodation websites (reviews, location/movement, consumption)

- Social media sites (opinions, photos, personal info, location/movement)

- Crowdsourcing and citizen science (maps, e.g., OpenStreetMap; local knowledge, e.g., Wikipedia; weather, e.g., Wunderground)

- Government bodies and public administration (services, performance, surveys)

- Financial institutions and retail chains (consumption, location)

- Private surveillance and security firms

(location, behaviour)

- Emergency services (security, crime, policing, response)

- Home appliances and entertainment systems (behaviour, consumption)

- Others? 


\section{Where is this data used?}

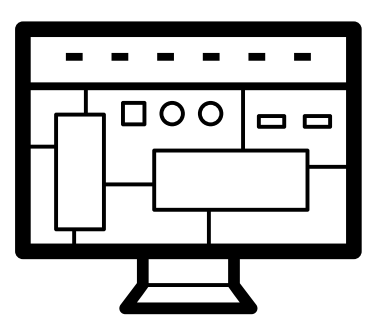

This depends on whether there's a high enough degree of coordination between city departments and sophisticated enough tech infrastructure in place. Ideally, data can be continually sent to city operating systems, intelligent transport systems, logistics management systems, smart energy grids, and building management systems that can process and respond in real-time to the data flow. 'Urban dashboards' enable city planners, and also citizens, to visualize and interact with a range of data, both traditional and real-time.

\section{How is this data used?}

Data comes alive in many ways, through data analysis, modelling, visualization, mapping, and more. Computer programs, also known as software, generally use a set of rules to parse, transform, and apply data to a range of situations. Software is made using math in the form of rules and equations, and often includes algorithms, a specific set of rules that achieve a mathematical function. Software is structured to process instructions and data to produce an output (much like a recipe). It allows complex tasks to be tackled that would be virtually impossible by hand.

This automation creates opportunities and risks - it can either reduce or amplify human error and bias in data, it can reduce costs and increase productivity through automation and it has the power to create new services and products. Many software programs use algorithms to do everyday practices and tasks, like searching, secure encrypted exchange, recommendations, pattern recognition, data compression, auto-correction, routing, predicting, profiling, simulation and optimization. As artificial intelligence and machine learning become more common, algorithms will be able to continually tweak and optimize themselves without any human intervention.

\section{Any questions?}

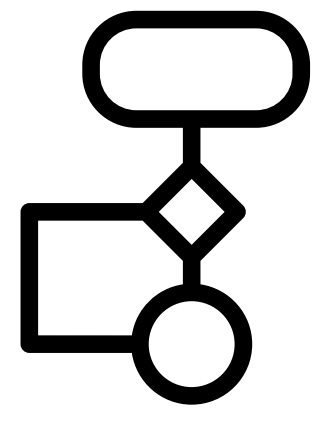




\section{Why does this matter to planners?}

Big data and smart city tech have huge potential to bring real improvements to the lives of urban citizens. But do the benefits outweigh the concerns? Here are a few reasons why planners ought to be concerned ${ }^{3}$ :

\section{The huge amounts of raw, unfiltered data generated in the smart city are useless to most users.}

Unless you have specific training in data management and analysis, data simply being available as they were collected - raw, unorganized, uncleaned - is a lot like looking for a needle in the world's biggest haystack. And unless you know what to look for, you won't be able to tell the difference between high and low quality data. This has a negative

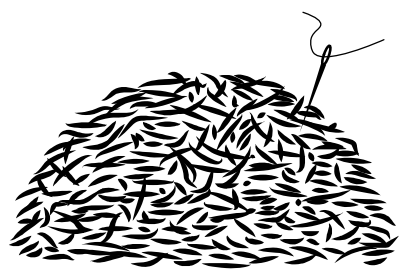
impact on grassroots efforts to actually make use of data to understand problems or create solutions at the local level.

\section{Decision-making and service delivery will increasingly be driven by big} data and algorithms, yet we can't easily 'look inside' and question how they work.

While city governments have been using software to manage service delivery and assist with administration for many years, the sophistication of cutting-edge smart city tech based on predictive algorithms means, more and more, this technology won't just support decision-making, it will drive it. But what happens when, for example, an algorithm tracking crime incidences causes some neighbourhoods or populations (e.g., Black, Indigenous, persons of colour, individuals experiencing homelessness, mental health issues or addictions) to experience greater policing and surveillance? Knowing how something works isn't necessarily enough to prevent it, but without the ability to 'open up the black box' of smart city algorithms and question the assumptions they're making, we have no practical way of beginning to challenge these outcomes. 


\section{Big data, while less visible than the built environment, will profoundly}

\section{change the urban experience.}

Who owns the data that are collected in the city? Privately-owned smart infrastructure (sensors, cameras, servers, etc.) and the data they collect could advantage some (i.e., firms with lots of resources) over smaller, local businesses who can't compete on the same scale. Planners concerned with equity should consider how individuals who don't possess smart technology or whose data isn't considered as valuable (e.g., for advertising purposes) might find themselves excluded or 'spatially sorted' - creating a new type of 'digital

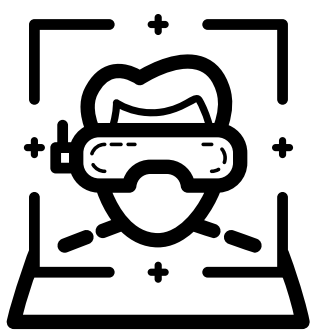
divide' in our cities.

\section{Tracking people's behaviour in public spaces, collecting and storing their data raises serious ethical questions around privacy and consent.}

Most of us are used to the idea that, when we use our smartphone to, say, tag ourselves in a photo taken at a restaurant, we're consenting to our location data being recorded (even if we didn't read the terms of use thoroughly). But how do we give (or withhold) consent as we move through a neighbourhood equipped with cameras and sensors? How do we know who is collecting our data and for what purpose? And if we're uncomfortable with our data being collected for unknown reasons, does that effectively make parts of the city off-limits to us? Can we, as planners, ethically use data in our work that's been obtained through coercion or uninformed consent?

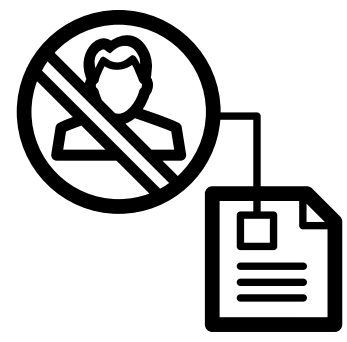

\section{Can you think of any others?}

The concerns described above are some of the most common raised by critics, but are by no means the only ones. Are there issues that you could see particularly impacting the community you work in? 


\section{Questions planners should ask about 'smart city' projects ${ }^{4}$}

Does the technology run on a proprietary platform, or is it open (source)?

\section{What kind of} opportunities for meaningful engagement with technology exist?
Who will own/control/ have access to the data that is captured by the sensors/cameras in this project?
Does this project strengthen existing civic institutions (e.g., public libraries) or undermine them?
How will the project balance its business needs with privacy, security and access concerns?
How can citizens opt-in or opt-out of being tracked or having their data collected?

Will people without access to technology (e.g., smartphone) be excluded from sharing the benefits of this project?

Can you think of more questions? 


\section{What can planners do?}

There are no easy answers to the issues outlined in the previous section. But, to begin with, here are several actions for planners to consider²:

\section{Communicate and curate data in an accessible way for public use.} Our Professional Code of Practice states that planners have a responsibility to "provide full, clear and accurate information on planning matters." In an era of big data, this means being proactive, readying datasets with public use in mind, and anticipating how grassroots planning efforts might use open data.

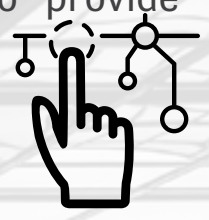

\section{Advocate for code and data used in public decision-making and} governance to be made open and available to scrutiny. While access to the inner workings of smart city software and algorithms won't

2 necessarily solve any problems in itself, it allows for the opportunity to credibly challenge and hold governments, service providers, or developers accountable and promote the public interest. Planners should hold smart city vendors and developers to a high standard of open access to data and data 우요응 infrastructure.

\section{Be responsible stewards of citizen data in all planning activities}

\section{3} As planners, we constantly use data to inform our work. We need to carefully weigh the ethical and privacy considerations involved in collecting identifiable personal or behavioural data. If the risks are too great, this means asking "do we need this?" and even deciding not to collect the data at all.

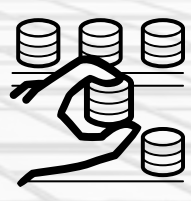

\section{Encourage developers to make solid plans for dealing with data} Private sector consultants should encourage their clients who are proposing smart city developments to anticipate and mitigate community concerns related to data transparency and privacy as much as possible in order to gain public support for their project. Municipal planners can play a role during pre-application consultations, advising proponents and providing a checklist of best practices on maintaining open data, personal privacy, and an accessible public realm.

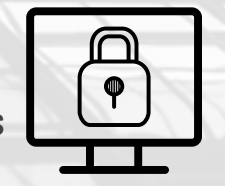




\section{Sources}

${ }^{1}$ Kitchin, R. (2016, September). Planning in an era of smart urbanism. Slideshow. Retrieved from https://www. slideshare.net/robkitchin/planning-in-an-era-of-smarturbanism

${ }^{2}$ Schweitzer, L. A., \& Afzalan, N. (2017). 09 F9 1102 9D 74 E3 5B D8 4156 C5 635688 C0: Four Reasons Why AICP Needs an Open Data Ethic. Journal of the American Planning Association, 83(2), 161-167. https:// doi.org/10.1080/01944363.2017.1290495

${ }^{3}$ Kitchin, R. (2016). Urban big data. Retrieved from https://www.theplanner.co.uk/features/urban-big-data

${ }^{4}$ Wylie, B. (2017). Civic Tech : A list of questions we'd like Sidewalk Labs to answer. Torontoist. Retrieved from https://torontoist.com/2017/10/civic-tech-list-questionswed-like-sidewalk-labs-answer/

\section{Created by Steve Coutts}

March 2018

Major Research Project Supplement

Content reviewed by:

Dr. Pamela Robinson

Bianca Wylie 


\section{Where can I learn more?}

Information on big data and smart cities becomes outdated almost as soon as it comes out. But here are a few resources that can act as starting points for

\section{Organizations}

Code for Canada - A national nonprofit that connects government innovators with the tech and design community. Their programs enable governments to deliver better digital public services and empower communities to solve civic challenges using technology and design.

codefor.ca

OpenNorth - Canada's leading not-for-profit organization specialized in open data, open government, community engagement, open smart cities and civic technology. opennorth.ca

Tech Reset Canada - A coalition of business people, technologists, and other residents advocating for innovation that is focused on maximizing the public good. techresetcanada.org

\section{Resources}

Book: Eubanks, V. (2017). Automating inequality: How high-tech tools profile, police, and punish the poor. New York: St. Martin's Press.

Book: Kitchin, R. (2014). The data revolution: Big data, open data, data infrastructures \& their consequences. Los Angeles, CA: SAGE.

Book: Kitchin, R., Lauriault, T. P., \& Wilson, M. W. (Eds.). (2017). Understanding spatial media. Los Angeles, CA: SAGE.

Book: Townsend, A. M. (2013). Smart cities: Big data, civic hackers, and the quest for a new utopia. New York: W.W. Norton.

Report: Gladstone, N., Flatt, J., Fader, J., \& Hellstern, M. (2018). How to be smart(er) in mid-sized cities in Ontario. Evergreen. Toronto.

https://www.evergreen.ca/downloads/pdfs/2018/tech-and-data-msc.pdf 
